\title{
Studies on the Physico-Chemical Parameters of Mailapur Reservoir at Yadigr District, Karnataka State
}

\author{
Basawarajeshwari Indur \\ Assistant Professor, \\ Department of P G Studies in Zoology, \\ Sharnbasva University, Kalaburagi \\ Corresponding author e-mail: rajeshwari.indur667@gmail.com
}

\begin{abstract}
The selected physico-chemical parameters were investigated for period of one year to determine the water quality of Mailapur reservoirs of Yadgir District, Karnataka State. Four stations were selected on the reservoirs to reflect the impact of anthropogenic and lotic habitats. Atmospheric temperature, water temperature, $\mathrm{pH}$, dissolved oxygen, total alkalinity, total hardness, chloride, nitrate, phosphate were analyzed monthly between June 2014 and May 2015 using standard methods and procedures. The ranges of these factors were found to be comparable to those reported for other man made reservoirs of different parts of state and country. The runoff water includes fertilizers from nearby agriculture lands enter in to the reservoir were found to have caused cultural eutrophication in the reservoir. The present status of reservoirs was influenced by human activities on the watershed, and with time, it will affect the water quality and fish production in the reservoir. The study concludes that the Mailapur reservoirs were good in water quality, high ecological status and useful for the fish production.
\end{abstract}

Keywords: Water quality, Mailapur reservoir, Yadgir District,

\section{INTRODUCTION:}

Expanding human population brought about by the opportunities of good water supply, irrigation, fish production recreation and navigation offered by Reservoirs has put enormous pressure and stress on the quality of water impounded by the reservoir. The impact of human activities in and around the reservoir is felt on the unique physical and chemical properties of water on which the sustenance of fish that inhabit the reservoir is built as well as to the functions of the reservoir (Moshood Keke Mustapha 2008). Physical and chemical limnology of a reservoir is most important in determination of Water quality and health of ecosystem (Sidnei et al., 1992). Reservoirs are important in supply of drinking water, irrigation, fish production, recreation and other purposes to which the water must have been impounded. Excessive nutrient inputs, eutrophication, acidification, heavy metal contamination, organic pollution and obnoxious fishing practices have impact on water quality of all inland ecosystems, which great influence on biodiversity of reservoirs The variations in physical factors like temperature, transparency and chemical properties of water like $\mathrm{PH}$, alkalinity, hardens, calcium, DO, nitrate, and phosphate provide valuable information on the quality of the water and ecological status of reservoir.

This study has been conducted to assess the water quality of Mailapur reservoir District Yadigr, state
Karnataka, which are extensively used for the purpose of drinking and fish production using some selected physico-chemical properties.

\section{MATERIALS AND METHODS}

Duplicate surface water samples were collected from $10 \mathrm{~cm}$ depth monthly from four stations of two reservoirs for the period of one year between June 2014 and May 2016. Surface water temperature, $\mathrm{pH}$ were measured on field only. The following factors selected as water quality parameters were measured using the methods described for each factor according to APHA(1995).

\section{RESULTS AND DISCUSSION} in table 1.

Physico-chemical Characteristics are presented

Atmospheric and Water Temperature is playing key role in all the aquatic ecosystem, which has great impact on biological metabolism, reproduction and other physical and chemical characteristics of water. It is necessary to study temperature variations in any aquatic ecosystem.

The atmospheric temperature of study area were recorded in at all the selected stations and presented in Fig.1 the atmospheric temperature values were varied between $27.2 \pm 2.9^{\circ} \mathrm{C}$ to $35 \pm 2.7^{\circ} \mathrm{C}$ in different seasons. Similarly the water temperatures also 


\section{International Journal of Research in Advent Technology, Vol.7, No.2, February 2019 E-ISSN: 2321-9637 \\ Available online at www.ijrat.org}

showed seasonal fluctuations at all the station (Fig. 2) of the reservoir. Water temperature was high in the summer season $(27.12 \pm 1.5)$ followed by south west monsoon season $(26.5 \pm 1.19)$ and north east monsoon $(21.09 \pm 1.8)$ respectively. Which is correlated with the atmophreric temperature. Similar trends were noticed by Rajashekhar and Vijaykumar, (2008) in fresh water body of Gulbarga district. Sharma et al., (2000) observed that water temperature fluctuate between $21^{\circ} \mathrm{C}$ to $29^{\circ} \mathrm{C}$ in the Udaipur lakes while studying limnology.

According to Chisty (2002), pH values are most important for plankton growth. During present study water $\mathrm{pH}$ values were found between $7.4 \pm 0.5$ to $8.5 \pm 0.22$ respectively. It is suggesting that alkalinity nature of the reservoir throughout the study period. The high values may be due to attributed agricultural discharge by surrounding fields and photosynthetic activity. The lowest values were recorded during the south west monsoon season may be due to the inflow of runoff water in to the reservoir.

The major source of oxygen supply in water is from two sources (a) atmospheric diffusion and (b) photosynthetic activity of plants. Dissolved oxygen consider to be one of the limiting parameter of water quality, which regulate the aquatic life. Dissolved oxygen is an important indicator of water quality, ecological status, productivity and health of a reservoir. This is due to its importance as a respiratory gas, and its use in biological and chemical reactions. Higher dissolved oxygen recorded in the rains could be as a result of low temperature and increased mixing of water. The maximum dissolved oxygen was recorded $(4.44 \pm 0.58 \mathrm{mg} / \mathrm{lit})$ in winter and minimum dissolved oxygen was recorded $(5.8 \pm 1.9 \mathrm{mg} / \mathrm{lit})$ in the summer season. While lowest values were noticed during the south west monsoon season.

The hardness of natural water is mainly determined by presence of carbonates, bicarbonates, sulphates, chlorides of calcium and magnesium. During the study year the total hardness of water was recorded between $(66.5 \pm 7.5$ to $102.02 \pm 9.5)$. The maximum values were observed in summer season and minimum $(66.5 \pm 7.5 \mathrm{mg} / \mathrm{lit})$ in winter season.

The alkalinity is represented by capacity of water to neutralize a strong acid and it is characterized by the presence of hydrogen ion; most of the alkalinity of water is due to dissolution of carbonate. The maximum alkalinity value $(141.25 \pm 2.05 \mathrm{mg} / \mathrm{lit})$ were recorded during summer season, while lower values were $(89.95 \pm 6.75 \mathrm{mg} / \mathrm{l})$ observed in monsoon season. These higher values were associated with the rate of phytoplankton growth.
Chloride is one of the most chemical parameters which is generally present in all the natural water bodies. The ecological importance of the chloride lies in its potential to regulate salinity of water and exert consequent osmotic stress on biotic communities. The higher values of chloride content was $(41.9 \pm 9.5 \mathrm{mg} / \mathrm{lit})$ recorded in summer season and lower value was observed during the winter season followed by south west monsoon season. The higher values of chloride content are coupled with evaporation process in presence of high amount of radiation in summer season. Similar results were reported by Swarnalatha and Nasing Rao (1998) and Umavathi et al., (2007) stated that higher concentration of chloride is association with increased level of pollution.

Effects of anthropogenic activities around reservoir and its watershed are much reflected on the variations in the concentrations of the contents like nitrate and phosphate. The concentrations of these ions were higher during the rainy season; because the period is usually the peak of agricultural activities around the reservoir. During the study period higher values of nitrate content was noticed during the south west monsoon season $(1.42 \pm 0.19 \mathrm{mg} / \mathrm{lit})$, where as lower values were noticed during the summer season. The runoff water from the near farming fields may be increase the high content of nitrate in the reservoir during the south west monsoon season, while lower values were attributed with high amount of utilization of nitrate content by phyto-plankton during the summer season respectively. Similarly phosphate content of present reservoir showed seasonal fluctuations during the study period. The lower values were recorded during the summer season $(0.22 \pm 0.04)$, while higher amount of phosphate was noticed during the south west monsoon season $(0.87 \pm 0.08)$ respectively. According to Carpenter et al., (1998), Carignan et al., (2000) and Armengol et al., (1999), the non-point source nutrients inputs from different sources leads to cause of eutrophication and water quality problems of reservoirs. Similar findings were made by Ranu (2001), Chisty (2002) during the study of Udaipur lakes.

\section{CONCLUSION}

In all, the ranges of physico-chemical properties of Mailapur Reservoir are comparable to those found in non polluted reservoirs, and are within the permissible limits of WHO (1997) for drinking water supply as well as fish production. The only visible threat to the water quality and fish production is cultural eutrophication which was more pronounced in the Mailapur reservoir, result of extensive activity of human on the site. There is an urgent need to address the 


\section{Available online at www.ijrat.org}

problem of cultural eutrophication in this reservoir to protect the water body, maintain its water quality and enhance fish production. This could be done through continuous monitoring the water quality of reservoir and creating awareness among people who are living surrounding the reservoir.

Table 1. Physico-chemical parameters of Mailapur reservoir

\begin{tabular}{|l|c|c|c|}
\hline \multicolumn{1}{|c|}{ Parameter/seasons } & NEM & Summer & SWM \\
\hline Temperature & $29.1 \pm 1.7$ & $35 \pm 2.7$ & $27.2 \pm 2.9$ \\
\hline Water temperature & $21.09 \pm 1.8$ & $27.12 \pm 1.5$ & $26.5 \pm 1.19$ \\
\hline pH & $8.5 \pm 0.22$ & $7.5 \pm 1.8$ & $7.4 \pm 0.5$ \\
\hline Dissolved oxygen & $4.3 \pm 2.2$ & $5.8 \pm 1.9$ & $4.44 \pm 0.58$ \\
\hline Alkalinity & $103 \pm 10.7$ & $141.25 \pm 2.05$ & $89.95 \pm 6.75$ \\
\hline Hardness & $66.5 \pm 7.4$ & $102.02 \pm 9.5$ & $96 \pm 5.2$ \\
\hline Chloride & $31.5 \pm 2.2$ & $41.9 \pm 9.5$ & $24.2 \pm 5.9$ \\
\hline Nitrate & $1.06 \pm 0.10$ & $0.94 \pm 0.06$ & $1.42 \pm 0.19$ \\
\hline Phosphate & $0.39 \pm 0.09$ & $0.22 \pm 0.04$ & $0.87 \pm 0.08$ \\
\hline
\end{tabular}

All the parameters are expressed in $\mathrm{mg} / \mathrm{lit}$, except Temperature and $\mathrm{pH}$

\section{Figure-1: Temperature}

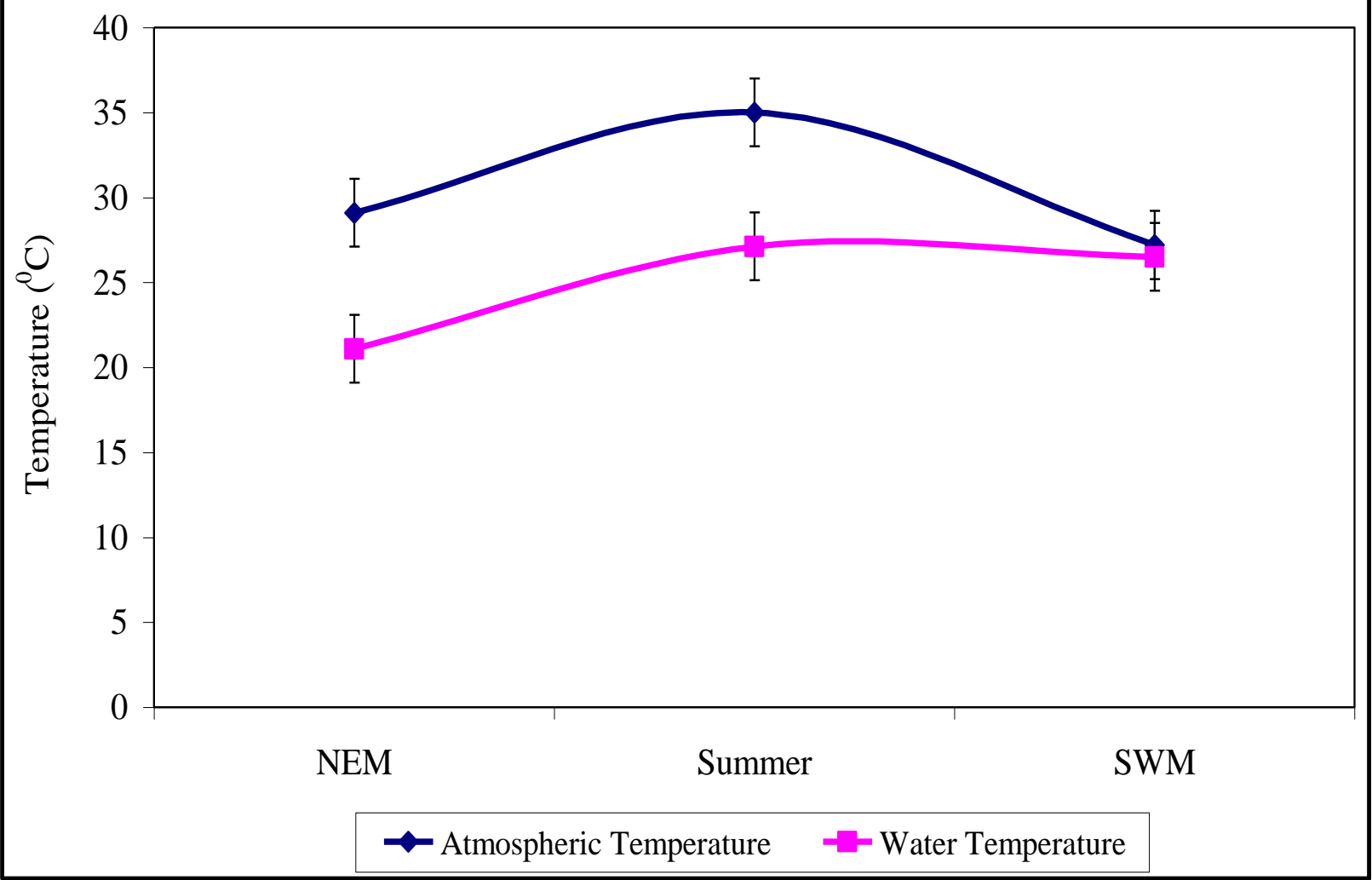


International Journal of Research in Advent Technology, Vol.7, No.2, February 2019 E-ISSN: 2321-9637

Available online at www.ijrat.org

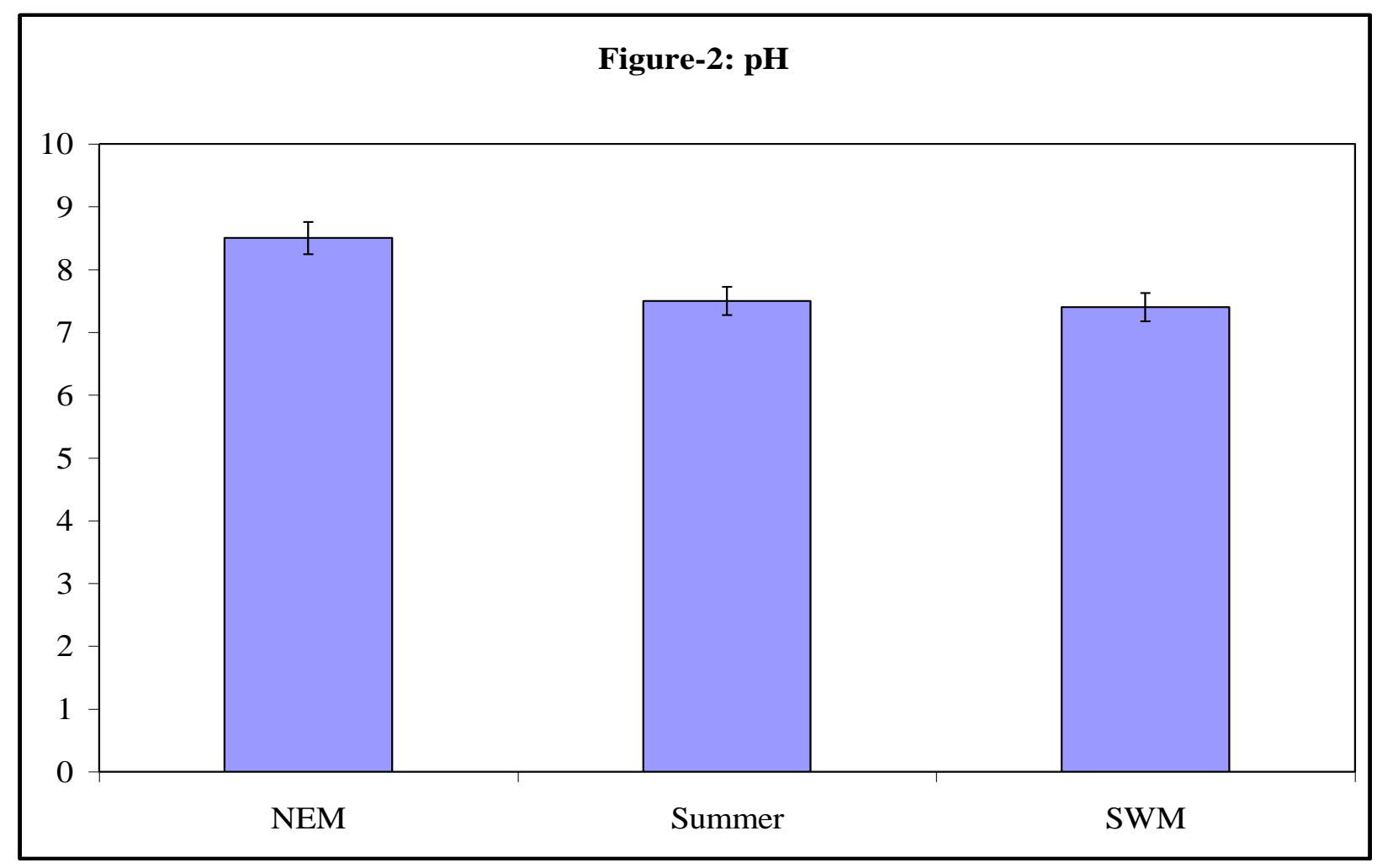

Figure-3: Dissolved oxygen

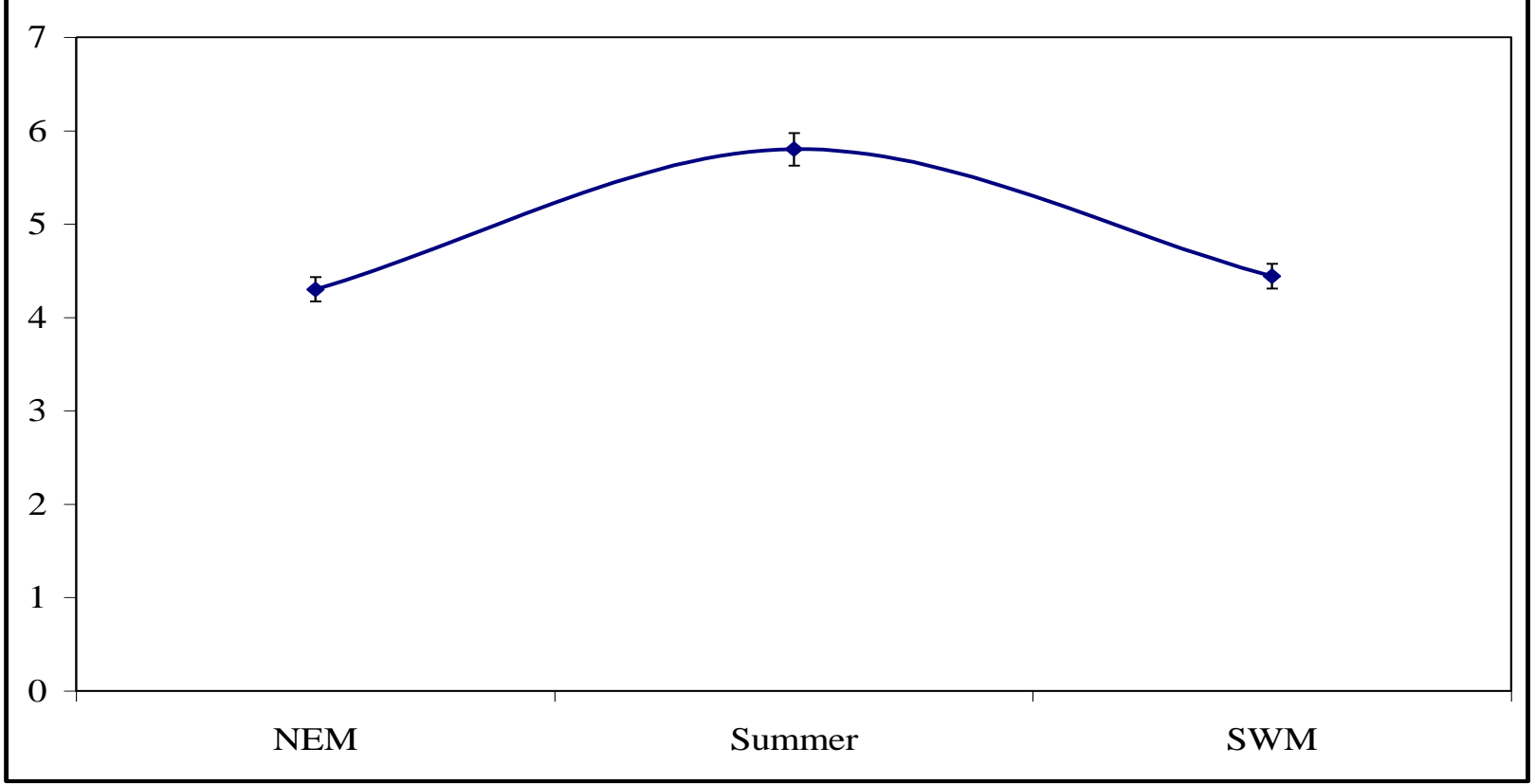


International Journal of Research in Advent Technology, Vol.7, No.2, February 2019 E-ISSN: 2321-9637

Available online at www.ijrat.org
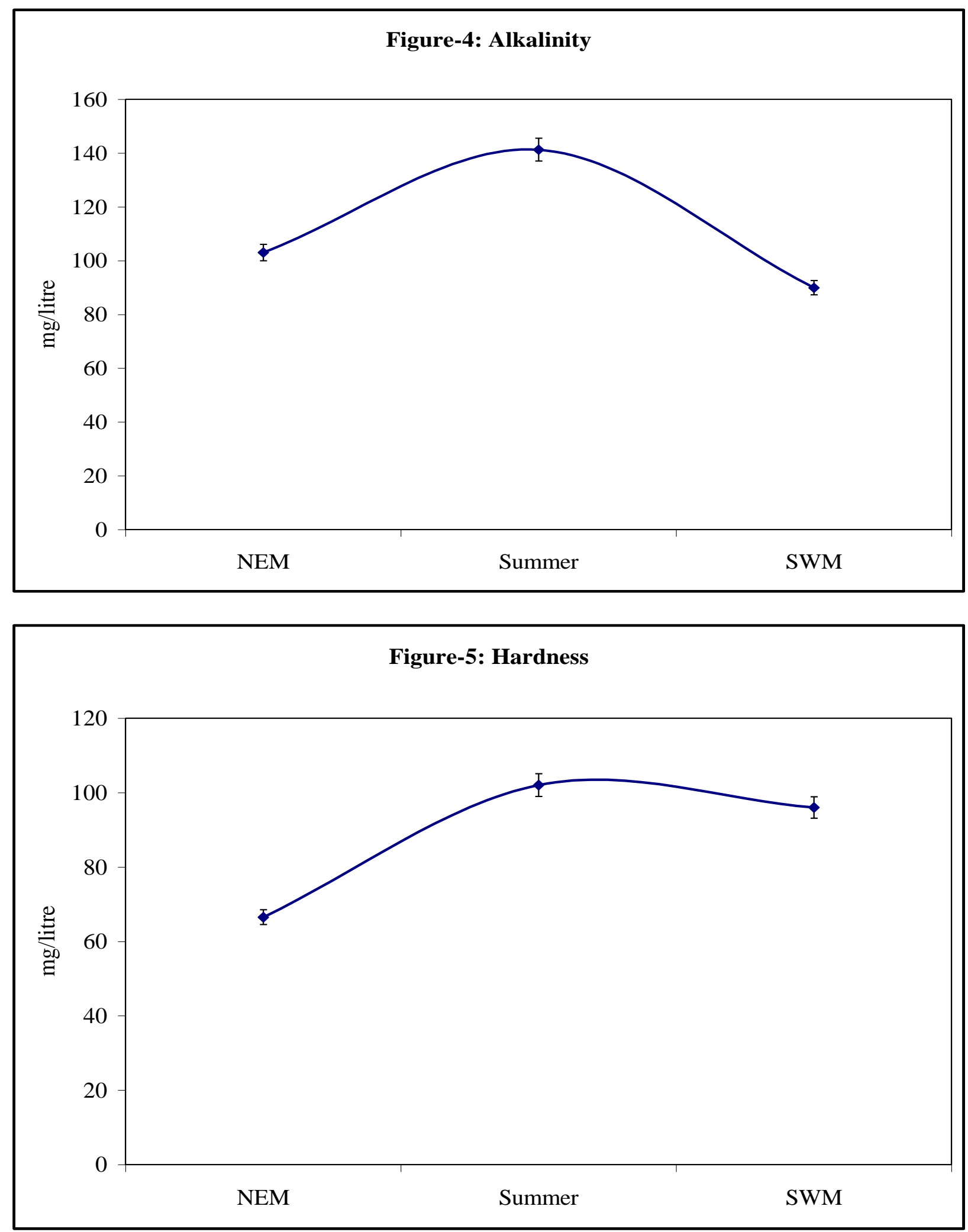
International Journal of Research in Advent Technology, Vol.7, No.2, February 2019 E-ISSN: 2321-9637

Available online at www.ijrat.org

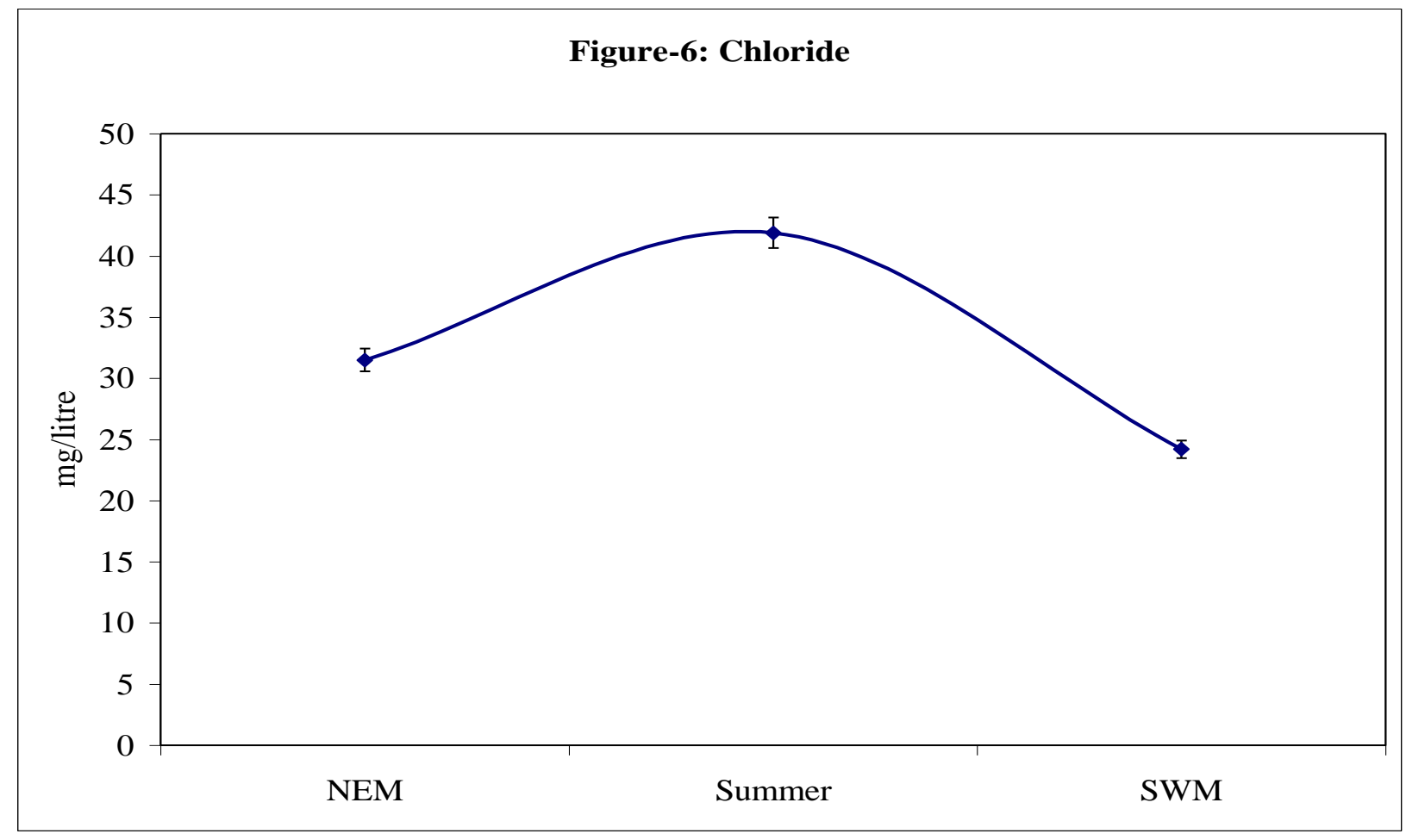

Figure-7: Nitrate

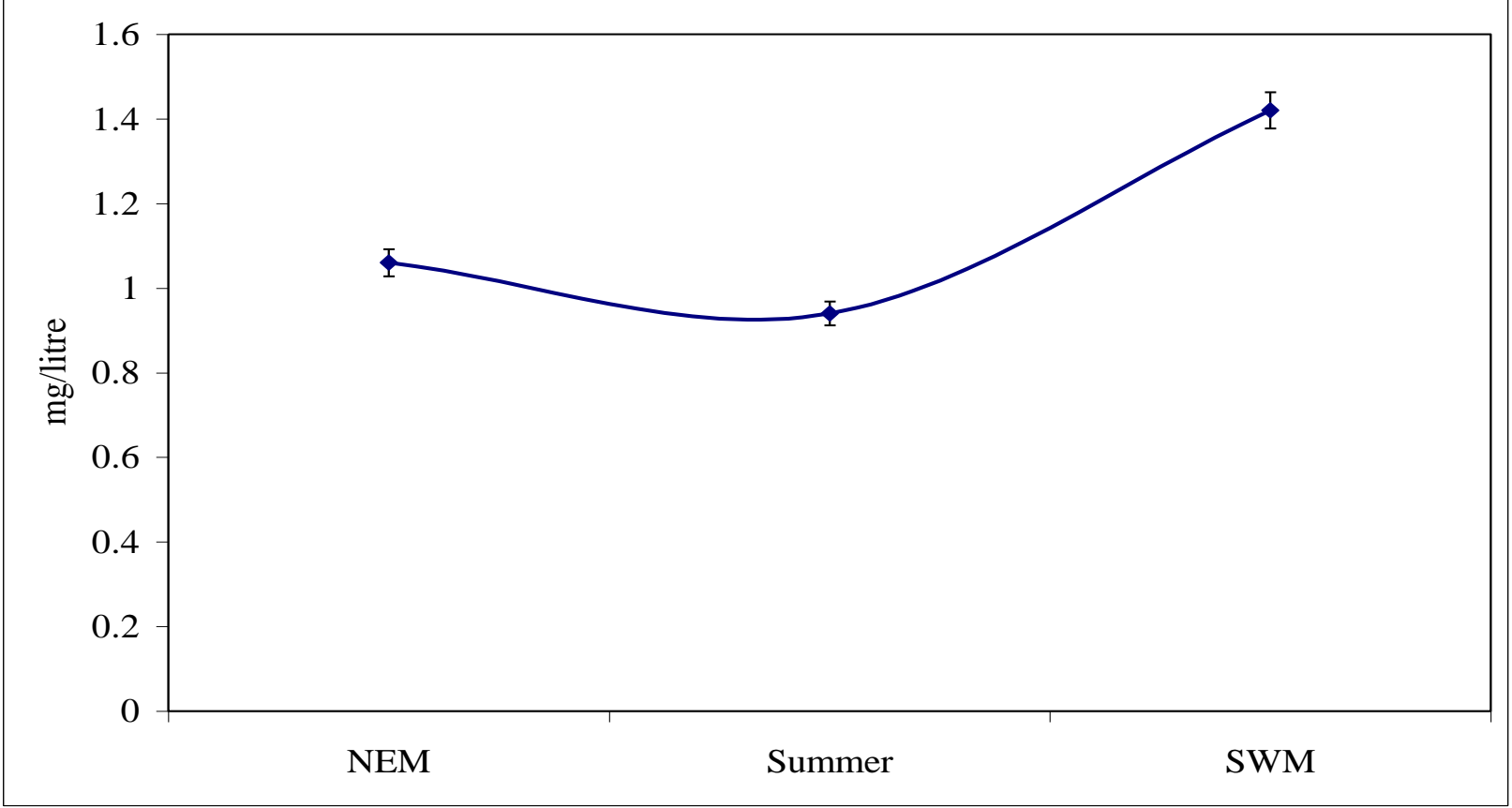




\section{Available online at www.ijrat.org}

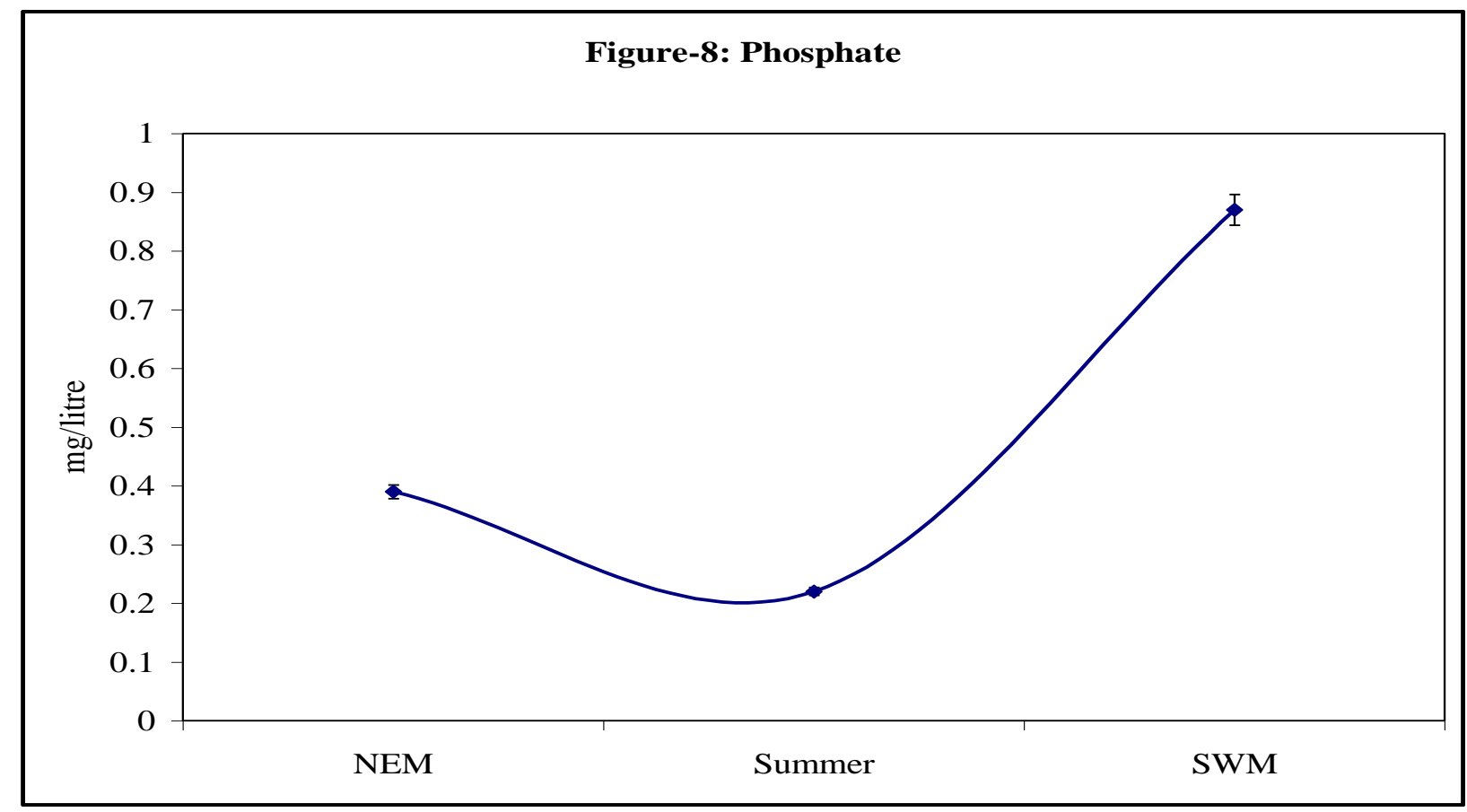

\section{REFERENCES}

[1] APHA (American Public Health Association) 1995. Standard methods for the examination of water and waste water. 19th edition. American Public Health Association Inc., New York, 1193 pp.

[2] Armengol, J., Garcia, J.C., Comerme, M., Romero, M., Dolz, J., Roura, M., Han, B.H., Vidal, A. and Simek, K. 1999. Longitudinal processes in Canyon type Reservoirs: The case of Sau (N.E. Spain). In: J.G. Tundisi and M. Straskraba (Eds.), Theoretical Reservoir Ecology and its Applications. IIE, Backhuys Publishers, Brazilian Academy of Science: $313-345$.

[3] Carignan, R., D'Arcy, P. and Lamonangne, S. 2000. Comparative impacts of fire and forest harvesting on water quality in Boreal Shield lakes. Canadian Journal of Fish and Aquatic Sciences, 57(2): 105117.

[4] Carpenter, S.R., Caranco, N.F., Correll, D.L., Howarth, R.W., Sharpley, A.N. and Smith, V.H. 1998. Non point pollution of surface waters with Phosphorous and Nitrogen. Ecological Applications, 8: 559-568.

[5] Chisty. N., (2002), Studies on Biodiversity of Freshwater Zooplankton in Relation to Toxicity of selected Heavy Metals. Ph. D. Thesis submitted to M.L Sukhadia University Udaipur.

[6] M. Rajashekhar and K. Vijaykumar (2008): Nutrients status in Sharanabasaveshwara Lake,
Gulbarga district, Karnataka, India. Int. J. Ecoscan: Vol. (2) Page 083-085.

[7] Ranu (2001), Studies on toxicity of textile effluents to fresh water Zooplankton. Ph.D. Thesis submitted to MLSU, Udaipur.

[8] Sharma, M. S. Liyaquat, F., Barbar, D. and Chisty, N., (2000), Biodiversity of freshwater zooplankton in relation to heavy metal pollution. Poll. Res., 19(1), pp 147-157.

[9] Sidnei, M.T., Fakio, A.L.T., Maria, C.R., Francises, A.E. and Adaunto, F. 1992. Seasonal

[10] variation of some limnological factors of Lagoa does Guarana, a Varzea lake of the Rio Paranana State of Mato Groso do Sul, Brazil. Rev. Hydrobiol., 25(4): 269-276.

[11] Swaranlatha, S. and A.Narsingrao., (1998), Ecological studies of Banjara lake with reference to water pollution, Journal of environmental biology , 19(2), pp 179-186.

[12] Umavathi, S., Longakumar, K and Subhashini., (2007), Studies on the nutrient content of Sulur pond in Coimbator, Tamil Nadu, Journal of ecology and environmental conservation, 13(5), pp 501-504. 